\title{
EVALUASI KUALITAS KODE DIAGNOSIS KETUBAN PECAH DINI PADA PASIEN RAWAT INAP
}

\author{
Warsi Maryati $\left.{ }^{a *}\right)$; Indriyati Oktaviano Rahayuningrum ${ }^{\mathrm{b}}$; Yohana Sulistyo Watic $^{\mathrm{c}}$ \\ a,b,c Jurusan Rekam Medis ; Universitas Duta Bangsa Surakarta \\ Jl. K.H. Samanhudi No. 93 Sondakan Laweyan Surakarta
}

\begin{abstract}
Abstrak
Ketuban pecah dini berada pada urutan ke 2 dalam 10 besar penyakit pasien rawat inap di salah satu rumah sakit swasta yang terdapat di Kabupaten Boyolali. Kualitas kode diagnosis ketuban pecah dini dapat menyebabkan hasil klaim pembiayaan pelayanan kesehatan pada sistem case mix dan penetapan kebijakan dalam pelayanan kesehatan tidak tepat. Penelitian ini mengevaluasi kualitas kode diagnosis ketuban pecah dini yang meliputi keakuratan, kelengkapan, konsistensi dan ketepatan waktu. Penelitian bersifat deskriptif dengan mengobservasi 215 dokumen rekam medis dan mewawancarai petugas coding. Hasil evaluasi menunjukkan kode diagnosis yang akurat sebanyak $58,60 \%$, kode diagnosis yang lengkap sebanyak $75,81 \%$, kode diagnosis yang konsisten 59,53\% dan rata-rata waktu untuk mengkode satu dokumen rekam medis antara 5-7 menit. Penyebab utama kode diagnosis tidak akurat, tidak lengkap dan tidak konsisten karena diagnosis tidak dikode dan kesalahan penentuan kode diagnosis pada karakter ke empat. Peningkatan kualitas kode sebaiknya dilakukan sehingga dalam pengambilan kebijakan dan penentuan biaya klaim asuransi lebih tepat.
\end{abstract}

Kata kunci: evaluasi, kode, ketuban, pecah, dini

\begin{abstract}
[EVALUATION OF QUALITY DIFFERENTIAL CULTURAL DIAGNOSIS CODE OF INFINED PAPER IN PATIENTS] Premature rupture of membranes ranks second in the top 10 inpatients diseases at one of the private hospitals in Boyolali Regency. The quality of the diagnosis of premature rupture of membranes could cause the results of health service financing claims in the case mix system and the determination of policies in health services is inappropriate. This study evaluated the quality of the diagnosis code for premature rupture of membranes which includes accuracy, completeness, consistency and timeliness. The study was descriptive by observing 215 medical record documents and interviewing the coding officer. Evaluation results showed an accurate diagnosis code of $58.60 \%$, a complete diagnosis code of $75.81 \%$, a consistent diagnosis code of $59.53 \%$ and the average time to code a medical record document between $5-7$ minutes. The main cause of the diagnosis code was inaccurate, incomplete and inconsistent because the diagnosis was not coded and the error in determining the diagnosis code in the fourth character. Improving the quality of the code should be done.
\end{abstract}

Keywords: evaluation, code, membranes, rupture, premature

\section{Pendahuluan}

Sarana pelayanan kesehatan merupakan lembaga yang mendukung kegiatan dalam mewujudkan tujuan nasional khususnya di bidang kesehatan. Berdasarkan Undang-Undang

\footnotetext{
*) Correspondence Author (Warsi Maryati)

E-mail: warsi_maryati@udb.ac.id
}

Republik Indonesia Nomor 44 Tahun 2009 pasal 1 ayat 1 tentang rumah sakit, bahwa rumah sakit berperan penting dalam menyelenggarakan pelayanan kesehatan perorangan secara paripurna. Upaya rumah sakit untuk meningkatkan pelayanan kesehatan dilakukan dengan cara memberikan pelayanan dengan baik 
dan bermutu kepada masyarakat, serta pengobatan dan perawatan harus didokumentasikan ke dalam rekam medis.

Menurut Permenkes RI Nomor
269/Menkes/Per/III/2008 pasal 1 ayat 1, rekam medis di dalamnya berisitentang catatan dan dokumen tentang identitas pasien, pemeriksaan, pengobatan, tindakan dan pelayanan lain yang telah diberikan kepada pasien. Pada instalasi rekam medis terdapat salah satu bagian yang penting di rumah sakit karena membantu dalam pengkodean diagnosis yang diberikan oleh dokter, salah satunya bagian yang berkaitan dengan pengkodean diagnosis yaitu bagian coding.

Coding merupakan salah satu bagian yang berkaitan dengan pemberian kode diagnosis dimana penetapan kode dengan menggunakan huruf atau angka atau kombinasi huruf dan angka yang mewakili komponen data berdasarkan International Statistical Clasification of Dieases and Related Health Problems Tenth Revision (ICD-10) (Depkes RI, 2006). Kode diagnosis berperan penting sebagai dasar penetapan biaya pelayanan kesehatan dan pengambilan kebijakan sehingga harus dijamin kualitasnya (Maryati, 2016). Keakuratan kode diagnosis berdampak pada perencanaan perawatan pasien di masa mendatang, penyediaan layanan kesehatan dan biaya pengobatan pasien (Cummings, 2011). Selain itu, kode diagnosis yang tidak konsisten dan tidak akurat memiliki implikasi besar bagi statistik nasional, analisis kinerja dan hasil klaim pembayaran (Dalal dan Roy, 2009). Hal tersebut juga sesuai dengan pendapat Thigpen (2015) bahwa ketidaktepatan kode diagnosis berimplikasi terhadap keuangan dan kebijakan yang sangat luas.

Kualitas kode diagnosis dipengaruhi oleh keakuratan dan kekonsistensian kode diagnosis, sehingga dapat menghasilkan kode yang tepat dan akurat. Kode diagnosis yang tidak berkualitas dapat merugikan rumah sakit, oleh karena itu sangat diperlukan evaluasi kode diagnosis. Evaluasi kode diagnosis dapat dilakukan dengan beberapa indikator meliputi, keakuratan (validity), kelengkapan (completenees), konsistensi (reliability) dan ketepatan waktu (timeliness) (Hatta, 2014), sehingga pelaksanaan pengkodean diagnosis oleh petugas coding harus sesuai dengan aturan ICD-10 (Depkes RI, 2006). Petugas coding harus memiliki pengetahuan dalam menetapkan kode diagnosis. ICD-10 volume 1 terdapat 22 bab, salah satu pada bab XV memuat tentang Pregnancy, Childbirth and the Puerperium dengan kode (O00-O99). Salah satunya Ketuban Pecah Dini (Premature rupture of membranes) dalam kategori (O42).

Ketuban Pecah Dini (KPD) adalah keadaan pecahnya selaput ketuban sebelum persalinan (Prawirohardjo, 2014). Insidensi ketuban pecah dini berkisar antara 5-10\% dari semua kelahiran. Ketuban pecah dini preterm terjadi 1\% dan $70 \%$ kasus ketuban pecah dini terjadi pada kehamilan aterm (Rohmawati, 2018). Pada 30\% kasus ketuban pecah dini merupakan penyebab kelahiran prematur (WHO, 2014). Insidensi ketuban pecah dini di Indonesia berkisar 4,5-6\% dari seluruh kehamilan (Rohmawati, 2018).

Berdasarkan survei pendahuluan yang dilakukan pada salah satu rumah milik organisasi sosial di Boyolali bertipe D, diagnosis ketuban pecah dini menempati urutan ke dua pada tahun 2018. Hasil evaluasi terhadap 10 dokumen rekam medis pasien rawat inap dengan diagnosis ketuban pecah dini, terdapat $70 \%$ kode diagnosis tidak akurat, 50\% kode diagnosis tidak lengkap, 60\% kode diagnosis tidak konsisten. Rumah sakit tersebut belum menetapkan standar waktu dalam pemberian kode diagnosis. Penelitian tentang kualitas kode diagnosis sudah banyak dilakukan sebelumnya, tetapi hanya fokus pada salah satu indikator saja yaitu ketepatan. Berdasarkan uraian di atas, maka dilakukan penelitian yang mengevaluasi kode diagnosis ketuban pecah dini pada dokumen rekam medis pasien rawat inap yang meliputi ketepatan, konsistensi, kelengkapan dan ketepatan waktu.

\section{Metode}

Jenis penelitian ini adalah penelitian deskriptif dengan pendekatan cross sectional. Penelitian ini menggambarkan tentang apa adanya mengenai variabel yang diteliti yang meliputi keakuratan, kelengkapan, konsistensi, dan standar waktu dalam pengkodean diagnosis ketuban pecah dini pada dokumen rekam medis pasien rawat inap. Penelitian dilakukan pada salah satu rumah sakit milik organisasi sosial (swasta) di Boyolali pada tahun 2018.

Populasi dalam penelitian ini yaitu dokumen rekam medis pasien rawat inap dengan diagnosis ketuban pecah dini tahun 2018 yang berjumlah 466 dokumen rekam medis. Sampel yang diteliti sebanyak 215 dokumen yang diambil menggunakan teknik pengambilan sampel acak sederhana (simple random sampling). Jumlah sampel penelitian diperoleh berdasarkan perhitungan menggunakan rumus Slovin dengan tingkat kesalahan $5 \%$. 
Sumber data dalam penelitian ini diperoleh dari hasil observasi dokumen rekam medis pasien rawat inap dengan ketuban pecah dini serta wawancara terhadap petugas coding. Data yang diamati meliputi diagnosis dan kode diagnosis pada resume medis dan resume masuk dan keluar, hasil pemeriksaan penunjang, SOAP, perjalanan penyakit dan pengobatan, laporan persalinan dan laporan tindakan. Keakuratan kode diagnosis dianalisis dengan mengkode kembali diagnosis ketuban pecah dini menggunakan ICD-10 kemudian membandingkannya dengan kode diagnosis yang terdapat dalam resume pasien. Kelengkapan kode diagnosis dianalisis dengan mengecek semua diagnosis pasien telah dikode, baik diagnosis utama maupun komplikasi dan komorbiditi. Konsistensi kode diagnosis dianalisis dengan meminta petugas coding untuk mengkode kembali kemudian membandingkan kode diagnosis hasil pengkodean petugas coding satu dengan petugas coding lainnya. Ketepatan waktu dalam mengkode diagnosis dianalisis dengan membandingkan waktu yang digunakan untuk mengkode diagnosis ketuban pecah dini dengan standar waktu yang telah ditetapkan oleh rumah sakit.

\section{Hasil dan Pembahasan}

Kualitas kode diagnosis diamati berdasarkan empat elemen review diantaranya keakuratan, kelengkapan, konsistensi dan ketepatan waktu mengkode diagnosis. Apabila salah satu elemen tidak terpenuhi, maka kode diagnosis menjadi tidak berkualitas dan dapat berpengaruh pada data statistik, biaya pelayanan kesehatan maupun pengambilan kebijakan. Berdasarkan hasil pengamatan diketahui tingkat kualitas kode diagnosis Ketuban pecah dini pasien rawat inap dapat dilihat pada Gambar 1.

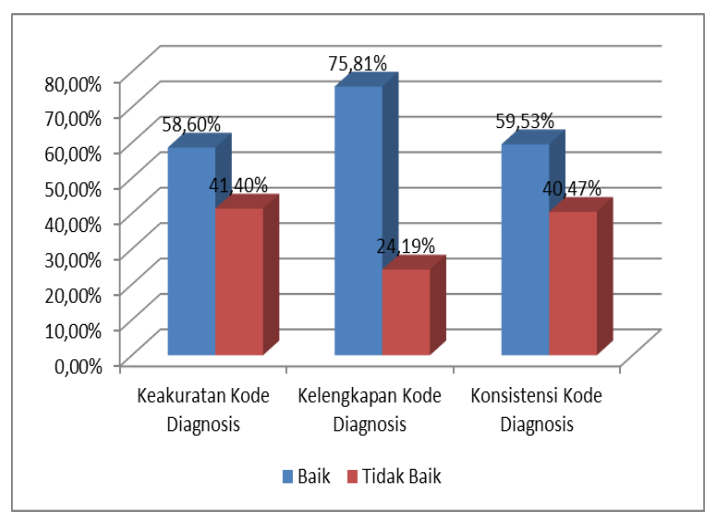

Gambar 1. Kualitas Kode Diagnosis Ketuban Pecah Dini
Evaluasi keakuratan dimaksudkan untuk mengetahui suatu kode diagnosis tepat sesuai dengan ICD-10. Berdasarkan hasil pengamatan diketahui tingkat keakuratan kode diagnosis Ketuban pecah dini pasien rawat inap dapat dilihat pada Gambar 2.

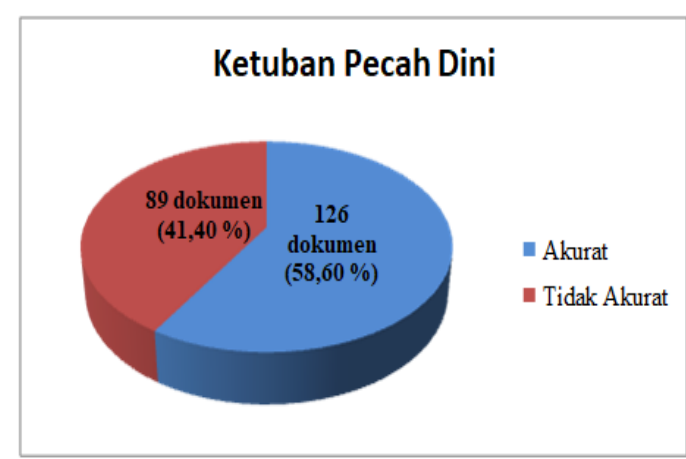

Gambar 2. Presentase Keakuratan Kode Diagnosis Ketuban Pecah Dini

Berdasarkan Gambar 2 dapat dilihat bahwa presentase keakuratan dan ketidakakuratan kode diagnosis Ketuban pecah dini ada 126 dokumen rekam medis pasien rawat inap yang akurat dengan presentase sebesar $58,60 \%$ dan 89 dokumen rekam medis pasien rawat inap yang tidak akurat dengan presentase $41,40 \%$ dari 215 dokumen rekam medis pasien rawat inap.

Klasifikasi ketidakakuratan kode diagnosis ketuban pecah dini diambil dari 89 dokumen rekam medis pasien rawat inap yang dikelompokkan menjadi 3 klasifikasi kode tidak akurat yaitu kode tidak akurat karena kesalahan pemberian kode pada karakter ke-4, kode tidak akurat karena kesalahan dalam penetapan kode diagnosis utama, dan kode tidak akurat karena tidak dikode. Jumlah dan persentase ketidakakuratan dari klasifikasi tersebut dapat dilihat pada Tabel 1.

Tabel 1 Klasifikasi Ketidakakuratan Kode Diagnosis Ketuban Pecah Dini

\begin{tabular}{lcc}
\hline \multicolumn{1}{c}{ Kode } & $\begin{array}{c}\text { Jumlah } \\
\text { Dokumen }\end{array}$ & $\begin{array}{c}\text { Presentase } \\
\text { (\%) }\end{array}$ \\
\hline $\begin{array}{l}\text { Salah Karakter } \\
\text { ke-4 }\end{array}$ & 35 & 39,34 \\
$\begin{array}{l}\text { Salah dalam } \\
\text { penetapan kode } \\
\text { diagnosis utama }\end{array}$ & 13 & 14,60 \\
\begin{tabular}{l} 
Tidak Dikode \\
\hline \multicolumn{1}{c}{ Jumlah }
\end{tabular} & 41 & 46,06 \\
\hline
\end{tabular}

Berdasarkan Tabel 1 dapat diketahui bahwa kode tidak akurat karena salah karakter ke- 4 
sebanyak 35 dokumen dengan presentase sebesar $39,34 \%$, kode tidak akurat karena salah dalam penetapan kode diagnosis utama ketuban pecah dini sebanyak 13 dokumen dengan presentase sebesar 14,60 \%, dan kode tidak akurat karena tidak dikode sebanyak 41 dokumen dengan presentase sebesar $46,06 \%$.

Ketidakakuratan kode karena salah pada karakter ke-4 pada diagnosis Ketuban pecah dini sebanyak 35 dokumen rekam medis. Jumlah ketidakakuratan paling tinggi sebanyak 34 dokumen dengan diagnosis ketuban pecah dini dimana kode dari rumah sakit adalah O42.0 sedangkan pada catatan perkembangan tertulis bahwa KPD lebih dari 24 jam, karena terdapat penjelasan saat ketuban pecah atau rembes dan pada lembar laporan persalinan tertulis waktu bayi lahir, sehingga peneliti mengkode O42.1. Ketidakakuratan kode karena salah pada karakter ke-4 terdapat 1 dokumen dengan diagnosis ketuban pecah dini dimana kode dari rumah sakit adalah O42.0 sedangkan pada catatan perkembangan tertulis bahwa pasien masih melanjutkan terapi dari dokter selama beberapa hari dan belum melahirkan, sehingga peneliti mengkode O42.2.

Ketidakakuratan kode disebabkan karena kurang telitinya petugas coding dalam membaca lembar catatan perkembangan pasien dan lembar pemeriksaan penunjang lainnya seperti lembar catatan keperawatan dan laporan persalinan. Penelitian ini sesuai dengan penelitian yang dilakukan oleh Maryati (2016), yang menyatakan bahwa kesalahan dalam karakter ke empat dapat menunjukkan bahwa kode diagnosis kurang spesifik dimana hal tersebut dapat disebabkan karena pengkode tidak memperhatikan informasi-informasi tambahan yang terdapat pada dokumen rekam medis. Menurut Wariyanti (2019), penulisan kode diagnosis utama yang tidak spesifik akan menghasilkan kode diagnosis utama yang tidak tepat lebih besar dibanding dengan penulisan kode diagnosis utama yang spesifik.

Dokumen rekam medis pasien rawat inap dengan diagnosis Ketuban pecah dini yang tidak akurat karena salah dalam penentuan kondisi utama sebanyak 13 dokumen. Ketidakakuratan kode dalam penentuan kode terjadi pada KPD dengan DKP dan PEB, sebanyak 10 dokumen terjadi pada KPD dengan DKP. Karena pada catatan perkembangan pasien terintegrasi tertulis pasien dirawat karena datang dengan indikasi dokter pinggul sempit, ketuban belum pecah saat pasien dalam perawatan dan pada laporan persalinan tertulis indikasi dokter adalah DKP dan KPD.

Ketidakakuratan kode pada KPD dengan PEB sebanyak 2 dokumen, karena pada lembar catatan perkembangan pasien terintegrasi dan lembar pemeriksaan fisik tertulis pasien masuk karena tekanan darahnya mencapai 190/100 hamil aterm dan pada lembar pemeriksaan laboratorium terdapat keterangan bahwa protein urin +3 . Sebanyak 1 dokumen, karena salah dalam penetapan pada diagnosis utama dimana kode dari rumah sakit adalah O80.9 sedangkan pada catatan perkembangan tertulis bahwa pasien dengan KPD kurang dari 24 jam dan terdapat penjelasan saat ketuban pecah atau rembes serta pada laporan persalinan tertulis waktu bayi lahir, sehingga peneliti mengkode O42.0

Dokumen rekam medis yang tidak dikode sebanyak 41 dokumen dengan diagnosis Ketuban pecah dini yang seharusnya dikode O42.0, O80.9, Z37.0. Hal ini dikarenakan petugas coding salah satunya coder pasien rawat inap merangkap sebagai petugas analisis kelengkapan sekaligus kepala unit rekam medis, menyebabkan coder kurang teliti dalam menuliskan kode diagnosis pada ringkasan masuk dan keluar. Hal ini dikarenakan pada beberapa dokumen rekam medis tidak ada keterangan yang jelas pada lembar-lembar pendukung yang dapat membantu petugas coding dalam memberikan kode penyakit dan petugas lupa atau dokumen terlewat sehingga tidak menuliskan pada lembar ringkasan masuk dan keluar (RM 1) melainkan hanya ditulis pada indeks komputer.

Hal ini sesuai dengan penelitian Ifalahma (2013) dan Octaria (2016) menyatakan bahwa dampak dari ketidakakuratan kode diagnosis penyakit akan berpengaruh terhadap besarnya klaim yang dibayarkan karena besarnya biaya klaim tergantung dari keakuratan kode diagnosis yang dimasukkan kedalam program INA-CBG's, sehingga ketidakakuratan ini berdampak besar terhadap pendapatan rumah sakit.

Evaluasi kelengkapan dimaksudkan untuk mengetahui apakah kode diagnosis sudah mencakup semua diagnosis yang ada di dokumen rekam medis atau belum. Berdasarkan hasil pengamatan tingkat kelengkapan kode diagnosis pasien rawat inap ketuban pecah dini pasien rawat inap dapat dilihat pada Gambar 3. 


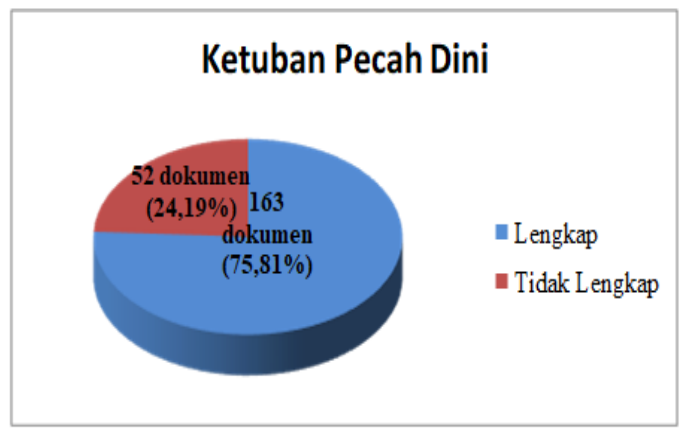

Gambar 3

Presentase Kelengkapan Kode Diagnosis Ketuban pecah dini

Berdasarkan Gambar 3 dapat dilihat hasil presentase kelengkapan kode diagnosis Ketuban pecah dini, kode lengkap sebanyak 163 dokumen rekam medis dengan presentase 75,81 \%, sedangkan untuk kode yang tidak lengkap sebanyak 52 dokumen rekam medis dengan presentase 24,19\% dari 215 dokumen rekam medis rawat inap. Klasifikasi ketidaklengkapan kode diagnosis ketuban pecah dini yang diambil dari 4 klasifikasi, karena tidak dikode, metode persalinan tidak dikode outcome of delivery tidak dikode, outcome of delivery tidak dikode, dan komplikasi tidak dikode. Jumlah dan presentase ketidaklengkapan dapat dilihat pada Tabel 2.

Tabel 2 Klasifikasi Ketidaklengkapan Kode Ketuban pecah dini

\begin{tabular}{lcc}
\hline \multicolumn{1}{c}{ Kode } & $\begin{array}{c}\text { Jumlah } \\
\text { Dokumen }\end{array}$ & $\begin{array}{c}\text { Presentase } \\
\mathbf{( \% )}\end{array}$ \\
\hline $\begin{array}{l}\text { Tidak } \\
\text { dilakukannya } \\
\text { pengkodean } \\
\text { Metode persalinan } \\
\text { dan outcome of } \\
\text { delivery tidak } \\
\text { dikode }\end{array}$ & 41 & 78,84 \\
$\begin{array}{l}\text { Outcome of delivery } \\
\text { tidak dikode }\end{array}$ & 5 & 7,70 \\
$\begin{array}{l}\text { Komplikasi tidak } \\
\text { dikode }\end{array}$ & 2 & 3,61 \\
\hline \multicolumn{1}{c}{ Jumlah } & 52 & 100 \\
\hline
\end{tabular}

Berdasarkan Tabel 2 dapat diketahui bahwa kode tidak lengkap karena tidak dilakukannya pengkodean paling tinggi sebanyak 41 dokumen dengan presentase sebesar 78,84\%, metode persalinan dan outcome of delivery tidak dikode sebanyak 4 dokumen dengan presentase sebesar $7,70 \%$, outcome of delivery tidak dikode sebanyak 5 dokumen dengan presentase sebesar 9,61\%, serta komplikasi tidak dikode sebanyak 2 dokumen dengan presentase 3,85 \%.

Kelengkapan kode diagnosis sudah sesuai dengan Hatta (2014), bahwa kualitas pengkodean diagnosis mencakup semua diagnosis dan tindakan yang ada di rekam medis (completness). Hal ini sesuai dengan penelitian Alik (2016), yang menyatakan bahwa pelaksanaan pengkodean diagnosa harus lengkap dan akurat sesuai arahan ICD-10, jika dalam pengkodean suatu penyakit tidak tepat maka akan mempengaruhi pengelolaan rekam medis terutama keakuratan data morbiditas dan mortalitas.

Tingkat ketidaklengkapan pada penelitian ini dikarenakan petugas coding lupa tidak menuliskan pada lembar RM 1 sehingga masih ditemukannya ketidaklengkapan kode dalam persalinan. Hal ini belum sesuai dengan WHO (2010), yang menyatakan bahwa minimum kode yang diperlukan pada kasus persalinan yaitu kondisi ibu atau janin, metode persalinan tunggal atau multiple, dan outcome of delivery tunggal atau multiple. Selain itu kode outcome of delivery juga digunakan untuk mengetahui angka kelahiran dan angka kematian bayi di rumah sakit.

Konsistensi merupakan salah satu elemen untuk mengevaluasi suatu kode diagnosis, dalam penelitian ini konsistensi dimaksudkan untuk mengetahui kesamaan dalam penetapan kode diagnosis antar petugas coding. Berdasarkan hasil pengamatan yang dilakukan tingkat konsistensi kode diagnosis dapat dilihat pada Gambar 4.

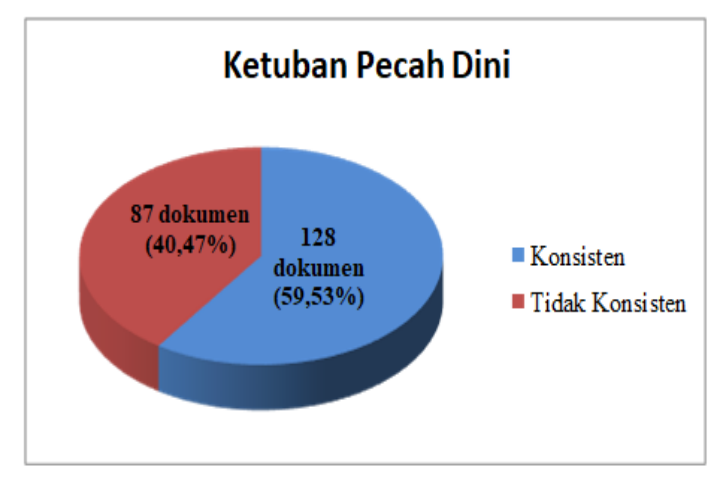

Gambar 4 Presentase Konsistensi Kode Diagnosis Ketuban pecah dini

Berdasarkan Gambar 4 presentase konsistensi kode diagnosis Ketuban pecah dini ada 128 dokumen rekam medis pasien rawat inap yang konsisten dengan presentase sebesar $59,53 \%$ dan 87 dokumen rekam medis pasien rawat inap yang tidak konsisten dengan 
presentase sebesar 40,47\% dari 215 dokumen rekam medis pasien rawat inap.

Klasifikasi ketidakkonsistensian kode diagnosis ketuban pecah dini diambil dari 87 dokumen rekam medis pasien rawat inap yang dikelompokkan menjadi 5 klasifikasi kode tidak konsisten yaitu kode tidak konsisten karena kesalahan pemberian kode pada karakter ke-4, kode tidak konsisten karena tidak dikode, kode tidak konsisten karena outcome of delivery tidak dikode, kode tidak konsisten karena metode persalinan dan outcome of delivery tidak dikode, serta kode tidak konsisten karena komplikasi tidak dikode. Jumlah dan persentase ketidakkonsistensian dari klasifikasi tersebut dapat dilihat pada Tabel 3.

Tabel 3 Klasifikasi Konsistensi Kode Diagnosis Ketuban Pecah Dini Pasien Rawat Inap

\begin{tabular}{lcc}
\hline \multicolumn{1}{c}{ Kode } & $\begin{array}{c}\text { Jumlah } \\
\text { Dokumen }\end{array}$ & $\begin{array}{c}\text { Presentase } \\
(\mathbf{\%})\end{array}$ \\
\hline $\begin{array}{l}\text { Salah karakter } \\
\text { ke-4 }\end{array}$ & 35 & 40,22 \\
$\begin{array}{l}\text { Tidak } \\
\text { dilakukannya } \\
\text { pengkodean }\end{array}$ & 41 & 47,13 \\
$\begin{array}{l}\text { Metode } \\
\text { persalinan dan } \\
\text { outcome of delivery } \\
\text { tidak dikode }\end{array}$ & & \\
$\begin{array}{l}\text { Outcome of delivery } \\
\text { tidak dikode }\end{array}$ & 5 & 5,60 \\
$\begin{array}{l}\text { Komplikasi tidak } \\
\text { dikode }\end{array}$ & 2 & 2,30 \\
\hline \multicolumn{1}{c}{ Jumlah } & 87 & 100 \\
\hline
\end{tabular}

Berdasarkan tabel 3 dapat diketahui bahwa kode tidak konsisten karena salah karakter ke-4 sebanyak 35 dokumen dengan presentase $40,22 \%$, kode tidak konsisten karena tidak dilakukannya pengkodean paling tinggi sebanyak 41 dokumen dengan presentase sebesar $47,13 \%$, metode persalinan dan outcome of delivery tidak dikode sebanyak 4 dokumen dengan presentase sebesar $4,60 \%$, outcome of delivery tidak dikode sebanyak 5 dokumen dengan presentase sebesar 5,57 \%, serta komplikasi tidak dikode sebanyak 2 dokumen dengan presentase $2,30 \%$.

Berdasarkan hasil wawancara ketidakkonsistensian disebabkan karena informasi medis yang tidak ditulis secara lengkap oleh dokter maupun perawat. Dokter dan perawat yang tidak menuliskan keterangan secara lengkap pada formulir rekam medis pasien dapat berpengaruh pada kualitas kode diagnosis, sebagai contoh pada kejadian Ketuban Pecah Dini yang tidak dituliskan secara rinci pada Lembar Pengkajian Awal IGD (Ningtyas, 2019).

Selain itu, petugas coding dalam menetapkan kode diagnosis hanya melihat pada diagnosis yang tertulis di dalam resume medis dan lembar ringkasan masuk dan keluar saja, serta proses mengkode berdasarkan ingatan atau hafalan petugas, yang menyebabkan untuk kode diagnosis ketuban pecah dini yang tertulis pada dokumen rekam medis pasien rawat inap yaitu O42.0 atau ketuban pecah dini kurang dari 24 jam. Hal ini sesuai dengan penelitian Farzandipour (2010), menyatakan bahwa kebiasaan mengkode berbasis memori tidak menjamin pengkodean yang akurat dalam kasus yang rumit dan kasus yang baru. Petugas coding apabila mengalami kesulitan dalam menetukan kode diagnosis yang lebih akurat, maka petugas coding sebaiknya melakukan komunikasi dan koordinasi antar petugas rekam medis, sehingga kode yang dihasilkan antar petugas lebih konsisten.

Ketepatan waktu merupakan salah satu elemen yang bertujuan untuk mengetahui suatu kode diagnosis, apakah sudah dikode sesuai dengan waktu yang telah ditetapkan atau belum. Berdasarkan hasil penelitian, pemberian kode diagnosis dilaksanakan setelah petugas coding menerima dokumen rekam medis pasien pulang dari verifikasi administrasi atau kasir, kemudian dokumen rekam medis pasien kembali ke ruang rekam medis, tidak ada standar waktu tertentu dalam pemberian kode diagnosis, pemberian kode diagnosis diberikan sesegera mungkin setelah dokumen rekam medis kembali. Pelaksanaan pemberian kode diagnosis meskipun tidak ada standar waktunya, tetapi waktu yang digunakan untuk mengkode satu dokumen rekam medis kurang lebih 5-7 menit.

Berdasarkan hasil wawancara pelaksanaan dalam pemberian kode diagnosis terkadang harus tertunda dikarenakan petugas medis seperti dokter maupun perawat tidak lengkap dalam menuliskan informasi medis di dalam dokumen rekam medis, sehingga dokumen akan dikembalikan ke bangsal yang terkait untuk segera dilengkapi, menyebabkan pelaksanaan pemberian kode diagnosis tertunda. Meskipun dokumen rekam medis dapat dikode dengan hasil yang dapat dipercaya, benar dan lengkap, tetapi jika tidak dikode tepat waktu akan menghambat penagihan biaya perawatan. Hasil 
penelitian Cheng (2009) menunjukkan bahwa klaim biaya pelayanan kesehatan di rumah sakit dalam sistem berbasis casemix sangat bergantung pada kodifikasi klinis yang tepat, komprehensif dan tepat waktu.

Berdasarkan hasil wawancara pelaksanaan pemberian kode diagnosis meskipun tidak ada standar waktu tetapi untuk pasien BPJS dokumen atau berkas pasien sudah harus kembali dalam waktu 1×24 jam. Hal ini sesuai dengan WHO (2014), yang menyatakan bahwa dokumen rekam medis di rumah sakit harus di proses dan diselesaikan kemudian dikode dan diindeks dalam jangka waktu tertentu.

\section{Simpulan dan Saran}

Keakuratan kode diagnosis ketuban pecah dini pasien rawat inap, presentase kode akurat sebanyak 58,60 \% dan presentase kode tidak akurat sebanyak $41,40 \%$ yang disebabkan karena kode salah pada karakter ke-4, salah dalam penetapan kode dagnosis utama, dan terdapat dokumen yang tidak dikode. Kelengkapan Kode Diagnosis Ketuban Pecah Dini Pasien Rawat Inap, presentase kode lengkap sebanyak 75,81 \% dan presentase kode tidak lengkap sebanyak 24,19\% yang disebabkan karena tidak dikode, metode persalinan dan outcome of delivery tidak dikode, outcome of delivery tidak dikode, dan komplikasi tidak dikode. Konsistensi Kode Diagnosis Ketuban Pecah Dini Pasien Rawat Inap, presentase kode konsisten sebanyak 59,53\% dan presentase kode tidak konsisten sebanyak $40,47 \%$. Standar waktu dalam pengkodean diagnosis Ketuban Pecah Dini pasien rawat inap belum ditetapkan, namun rata-rata waktu yang dibutuhkan untuk mengkode antara 5-7 menit.

Sebaiknya untuk meningkatkan presentase keakuratan, kelengkapan, dan konsistensi kode diagnosis, perlu diadakannya review dan pengecekan ulang dalam memberikan kode diagnosis ketuban pecah dini untuk lebih spesifik dalam menentukan kode sehingga kode yang dihasilkan lebih akurat, tepat, dan sesuai, serta perlu diadakannya aturan secara tertulis mengenai standar waktu dalam pemberian kode diagnosis. Petugas coding sebaiknya juga membaca seluruh informasi medis pasien dengan cermat dan mengkode diagnosis sesuai aturan ICD-10, bukan berdasarkan memori (ingatan). Penelitian ini hanya dapat menggambarkan persentase keakuratan, kelengkapan dan konsistensi kode diagnosis, sedangkan persentase ketepatan waktu dalam penetapan kode diagnosis belum dapat digambarkan karena belum terdapat standar waktu mengkode diagnosis. Selain itu, keterbatasan penelitian ini juga belum dapat membuktikan dampak kualitas kode diagnosis yang kurang baik terhadap pembiayaan pelayanan kesehatan secara empiris. Bagi peneliti berikutnya, penulis menyarankan untuk mengembangkan penelitian kualitatif ini ke arah penelitian kuantitatif dengan menghubungkan kualitas kode diagnosis terhadap ketepatan klaim biaya pelayanan kesehatan.

\section{Ucapan Terima Kasih}

Terimakasih disampaikan kepada Universitas Duta Bangsa Surakarta yang telah mendukung keberlangsungan penelitian ini dan tempat penelitian serta para responden yang memberikan ijin dan membantu dalam pengumpulan data penelitian. Ucapan terimakasih juga disampaikan kepada seluruh pihak yang telah membantu menyelesaikan penelitian ini yang tidak dapat peneliti sebutkan satu per satu.

\section{Daftar Pustaka}

Alik, A.T.N.I. (2016). Hubungan Ketepatan Kode Diagnosa Obstetric Terhadap Kelancaran Klaim BPJS Di RSUD Sawerigading Kota Palopo Sulawesi Selatan. Jurnal INOHIM. 4 (1) : 1-10.

Cheng, P., Gilchrist, A., Robinson, K.M., Paul, L. (2009). The Risk and Consequences of Clinical Miscoding due to Inadequate Medical Documentation : A Case Study of the Impact on Health Services Funding. Health Information Management Journal, 38 (1): 35-46.

Cummings, E., Maher, R., Showell, C.M., Croft, T.; Tolman, J., Vickers, J., Stirling, C., Robinson, A., Turner, P. (2011). Hospital coding of Dementia: is it accurate?. Health Information Management Journal, 40 (3): 5-11.

Dalal, S., Roy, B. (2009). Reliability of Clinical Coding of Hip Fracture Surgery: Implications for Payment by Results?. Inernational Journal Care Injured, 40 (1):738-741.

Departemen Kesehatan RI. (2006). Pedoman Penyelenggaraan dan Prosedur Rekam Medis Rumah Sakit. Jakarta : Direktorat Jenderal Bina Pelayanan Medik. 
Farzandipour, M., Sheikhtaheri, A., Sadoughi, F. (2010). Effecctive Factors on Accuracy of Principal Diagnosis Coding Based on International Classification of Disease, the 10th Revision (ICD-10). International Journal of Information Management. 30 (5) : 78-84

Hatta, G. (2014). Pedoman Manajemen Informasi Kesehatan di Sarana Pelayanan Kesehatan. Edisi Revisi.Jakarta : Universitas Indonesia (UI-Press).

Ifalahma, D. (2013). Hubungan Pengetahuan Coder dengan Keakuratan Kode Diagnosis Pasien Rawat Inap Jaminan Kesehatan Masyarakat Berdasarkan ICD-10 di RSUD Simo Boyolali, Jurnal Informasi Kesehatan, 3 (2): 14-26.

Maryati, W. (2016). Hubungan Antara Ketepatan Penulisan Diagnosis Dengan Keakuratan Kode Diagnosis Kasus Obstetri di PKU Muhammadiyah Sukoharjo. Jurnal Ilmiah Rekam Medis dan Informasi Kesehatan, 6 (2) : 1-7.

Maryati, W., Murti, B., Indarto, D. (2016). Faktor-faktor yang Berpengaruh Terhadap Kualitas Kode Diagnosis Pasien Rawat Inap di RSUD Dr. Moewardi.Program Studi Ilmu Kesehatan Masyarakat. Program Pascasarjana Universitas Sebelas Maret. 1 (2) : 61-70.

Menteri Kesehatan RI. (2008). Peraturan Menteri Kesehatan No. 269/MENKES/PER/III/2008 Tentang Rekam Medis. Jakarta.

Ningtyas, N.K, Sugiarsi, S, Wariyanti, A.S. (2019). Analisis Ketepatan Kode Diagnosis Utama Kasus Persalinan Sebelum dan Sesudah Verifikasi pada Pasien BPJS di RSUP Dr. Soeradji Tirtonegoro Klaten. Jurnal
Kesehatan Vokasional, 4(1): 1-11.

Octaria, H. (2016). Peningkatan Kualitas Pengkodean Pada Ketepatan dan Kecepatan Pengkodean Penyakit Untuk Penagihan Klaim BPJS di RSUD Petala Bumi Pekanbaru. Jurnal Manajemen Informasi Kesehatan Indonesia. 4 (1) : 12-20.

Prawirohardjo, S. (2014). Ilmu Kebidanan. Jakarta : PT Bina Pustaka Sarwono Prawirohardjo.

Republik Indonesia. (2009). Undang-Undang Republik Indonesia Nomor 44 tahun 2009 Tentang Rumah Sakit. Jakarta.

Rohmawati, N., Fibriana, I.A. (2018). Ketuban Pecah Dini di Rumah Sakit Daerah Ungaran. Jurusan Ilmu Kesehatan Masyarakat. 2 (1) : 23-32.

Thigpen, J.L., Pharm, Dillon, C., Forster, K.B., Henault, L., Quinn, E.K., Tripodis, Y., Berger, P.B., Hylek, E.M., Limdi, N.A. (2015). Validity of International Classification of Disease Codes to Identify Ischemic Stroke and Intracranial Hemorrhage among Individuals with Associated Diagnosis of Atrial Fibrillation. Circulatory Cardiovascular Quaility Outcomes, 8 (1): 8-14.

Wariyanti, S, A., Sugiarsi, S., Ningtyas, K, N. (2019). Analisis Ketepatan Kode Diagnosis Utama Kasus Persalinan Sebelum dan Sesudah Verifikasi pada Pasien BPJS di RSUP Dr. Soeradji Tirtonegoro Klaten. Jurnal Kesehatan Vokasional. 4 (1) : 1-11.

WHO. (2010). International Statistical Classification of Disease and Related Health Problem Tenth Revision Volume 1,2,3. Geneva.

WHO. (2014). Improving Data Quality: A Guide For Developing Countries. WHO Westren Pasific Regional. 